\title{
EHMTI-0324. Expression of high-mobility group box 1 in the cerebral cortex after cortical spreading depression
}

\author{
T Takizawa*, M Shibata, Y Kayama, T Shimizu, H Toriumi, T Ebine, A Koh, N Suzuki \\ From 4th European Headache and Migraine Trust International Congress: EHMTIC 2014 \\ Copenhagen, Denmark. 18-21 September 2014
}

\section{Introduction and aims}

HMGB1 (high-mobility group box 1), which can serve as both a DNA-binding protein and a cytokine-like secretory molecule, has been implicated in the pathophysiological processes initiated by cortical spreading depression (CSD). Here, we examined the expression of HMGB1 at the RNA and protein levels in the cerebral cortex subjected to CSD.

\section{Methods}

CSD was induced by applying $1 \mathrm{M} \mathrm{KCl}$ to the cerebral cortex in male C57BL/6 mice. The induction of CSD was monitored by recording DC potentials at an electrode close to the CSD induction site. To examine HMGB1 expression, immunohistochemistry and in situ hybridization were performed for 10 micrometers-thick sections prepared from the cerebral cortices exposed to CSD. Nontreated control mice and sham-operated mice were also investigated.

\section{Results}

The basal expression of HMGB1 transcript and protein was identified in neurons and astrocytes with HMGB1 immunoreactivity being localized exclusively within the nucleus. At 3 hours after CSD induction, the HMGB1 transcription level was more marked in the cerebral cortex subjected to multiple CSD (5 times) compared to single CSD. At 24 hours after CSD induction, the HMGB1 transcriptional activity returned to the basal level. Meanwhile, HMGB1 immunoreactivity was recognized in the cytoplasm as well as within the nucleus in a small proportion of neurons in the cerebral cortex subjected to CSD.

\section{Conclusions}

CSD causes the release of HMGB1 from the nucleus in cortical neurons. Transient transcriptional upregulation of HMGB1 is driven by CSD, apparently contributing to replenishment of the molecule after its release.

No conflict of interest.

Published: 18 September 2014

doi:10.1186/1129-2377-15-S1-F26

Cite this article as: Takizawa et al: EHMTI-0324. Expression of highmobility group box 1 in the cerebral cortex after cortical spreading depression. The Journal of Headache and Pain 2014 15(Suppl 1):F26.

\section{SpringerOpen ${ }^{\circ}$}

( 2014 Takizawa et al; licensee Springer. This is an Open Access article distributed under the terms of the Creative Commons Attribution License (http://creativecommons.org/licenses/by/2.0), which permits unrestricted use, distribution, and reproduction in any medium, provided the original work is properly cited.
Submit your manuscript to a SpringerOpen ${ }^{\circ}$ journal and benefit from:

- Convenient online submission

- Rigorous peer review

- Immediate publication on acceptance

- Open access: articles freely available online

- High visibility within the field

- Retaining the copyright to your article

Submit your next manuscript at $>$ springeropen.com 